\title{
EXPLORATORY FACTOR ANALYSIS OF INVESTMENT PLAN IN INDIA
}

\author{
Dr.Jyoti Badge \\ Assistant Professor,VIT Bhopal University
}

\begin{abstract}
Savings and investments are the two essential ingredients of the capital formation of any country. Now a day's there are multiple options are available for investments and saving.The present paper focuses on various investment options like Banks, LIC, PPF, Bonds, Mutual Funds, Real estate, Commodity Market, Gold, Equity Shares, Futures \& Options, and instruments of the Post Office like NSC \& MIS to trace the preference of an investor. A survey of 300 respondents has been carried for finding the best investment options available in the current situation. Data analysis has been done by statistical tools like descriptive statistics and exploratory factor analysis
\end{abstract}

Key Words: Investments Options, Descriptive Statistical Analysis, Exploratory Factor Analysis

\section{Introduction}

Developing countries, like India, require a high rate of capital formation to secure the desired level of growth. Investments are largely depending upon the behavior of the investor as well as the availability of different investment avenues. The choice is required to be made amongst available alternative options for investments. An awareness of these investment avenues is extremely important to make the right investment decisions that will suit the different needs of different individuals. To trace the real aspects of different investments option's present study is mainly focusing on- Banks, LIC, PPF, Bonds, Mutual Funds, Real Estate, Commodity Market, Gold, Equity Shares, Futures \& Options, and instruments of Post Office like NSC \& MIS. The study discusses the investment options and preferences of investors towards the various investment alternatives. Primary data has been collected through a questionnaire. 300 respondents have been taken for the study. Descriptive statistics and Factor Analysis have been used for finding the best investment options in the current scenario in India

\section{Literature Review}

1. (S.Poongavanam et.al, 2013) studied investment in the Indian scenario. They found that Indian economic reforms, annual growth rate, curbing inflation rate, etc are beneficial for the domestic and foreign investment in recent years. Investors should understand about investing in India for long term growth.
2. (Reddy, 2017) presented a study on an analysis on investment in mutual funds through systematic investment planning a smart investors preference. He found that the most influencing factors for the selection of Mutual Fund scheme in India are high returns, net asset value, market trends, tax policy, and reputation of mutual fund in their order of priority. Most of the investors preferred to invest their money in open-ended schemes of Mutual Funds

3. (Mubeen, 2018), presented a paper on the perception of Indian women investors towards investment in mutual funds. This paper marked an attempt to identify various factors affecting the perception of women investors regarding investment in mutual funds. He suggested that mutual fund companies have to identify the areas required for improvement to create greater awareness among women investors regarding investment in mutual funds

4. (Lanjekar, 2018), conducted a study on saving and investment patterns of salaried class people with special reference to Pune city (India). The researcher hadanalyzed and found that that salaried employees considered the safety as well as a good return on investment that is invested on regular basis. Respondents are much more aware of the different investment avenues available in India except for female investors.

5. (Pandey, 2019 )studied on savings and capital formation in India. The paper 
highlighted the issues in infrastructure and MSME financing and proposed an agenda for reforms. Reduced financial repression, deep and liquid bond markets, improvement in banking regulation, improved access to bank credit to MSMEs should be the plan for financial sector reforms.

\section{Objectives of the study}

1. To understand the awareness level of the people about various investment avenues.

2. To find out the most preferred investment avenues among the people.

3. To understand and analyze the factors considered for investing.

4. To find out the overall criterion of investors regarding investment.

\section{$\underline{\text { Research methodology }}$}

- Data Collection: The present study is mainly based on primary data. The required data were collected through a questionnaire.

- Sources of Data: Primary data was collected through a questionnaire and Secondary data was collected from the reports, articles, journals, documents, printed literature, certain websites, and other online databases, etc.

- Sample Size The study has taken around 300 respondents who are the part of working population in few cities in MP.

- Investment Avenues covered in this paper: Banks, LIC, PPF, Bonds, Mutual Funds, Real estate, Commodity Market, Gold, Equity Shares, Futures \& Options and instruments of Post Office like NSC \& MIS.

- Statistical tools used: Analysis of data and interpretation is done by using Descriptive analysis and Factor Analysis(Jamie DeCoster, 1998)

- Limitations:Time Constraints was considered to be the major limitation of the study. The study is limited to the extent of the availability of data. The study has been restricted to only a few cities in MP.

\section{$\underline{\text { Analysis and Interpretation }}$}

\section{Personal Profile of the People:}

Table 1:Age of the respondents

\begin{tabular}{|c|c|c|}
\hline Age & Frequency & Percentage \\
\hline 20-40 years & 170 & 56.7 \\
\hline 41-60 years & 110 & 36.7 \\
\hline Above 60 years & 20 & 6.6 \\
\hline Total & 300 & 100 \\
\hline
\end{tabular}

From the above table, it can be inferred that the majority of the respondents $(56.7 \%)$ belong to the age group of $20-40$ years. A $(36.7 \%)$ of the respondents are fall in the age group of 41-60 years. A $(6.6 \%)$ of the respondent belong $s$ to the age group of above 60 years 


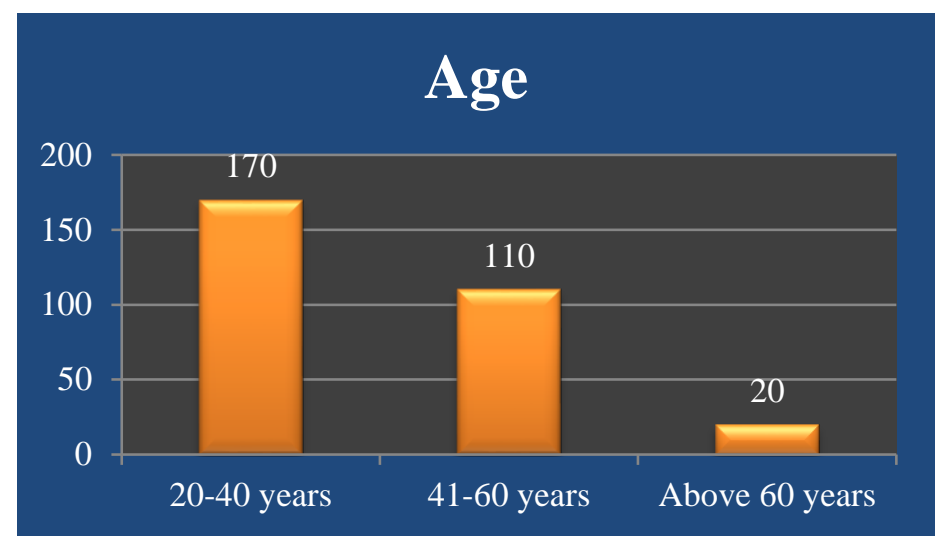

Figure 1

\section{Gender of the respondents}

Table 2: Gender of the respondents

\begin{tabular}{|l|l|l|}
\hline Gender & Frequency & Percentage \\
\hline Male & 200 & 66.7 \\
\hline Female & 100 & 33.3 \\
\hline Total & 300 & 100 \\
\hline
\end{tabular}

The above table representing that the majority of the respondents are male. Only $33.3 \%$ of the respondents are female.

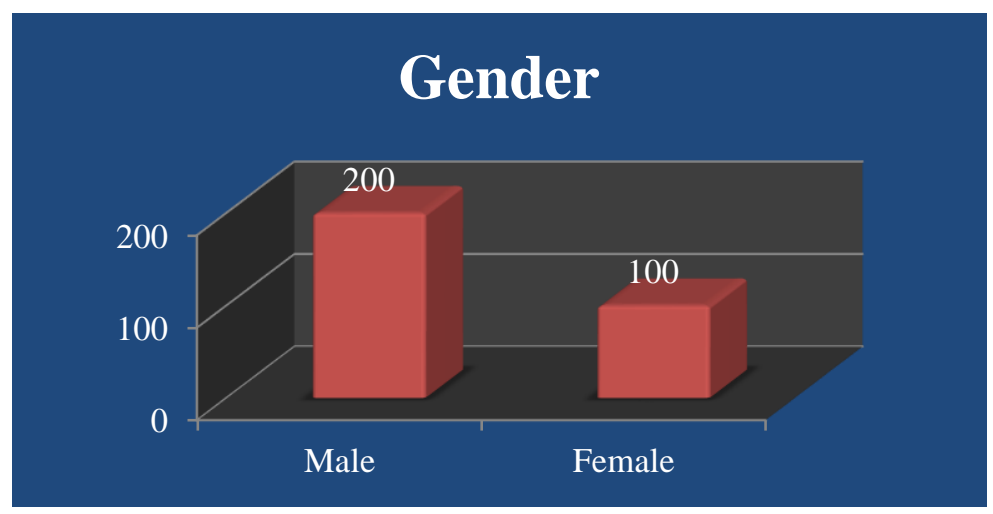

Figure 2

\section{Marital Status}

Table 3:Marital Status of the respondents

\begin{tabular}{|l|l|l|}
\hline Marital Status & Frequency & Percentage \\
\hline Married & 230 & 76.7 \\
\hline Unmarried & 70 & 23.3 \\
\hline Total & 300 & 100 \\
\hline
\end{tabular}

From the above table, it is clear that $76.7 \%$ of respondents are married and $23.3 \%$ of respondents are unmarried. 


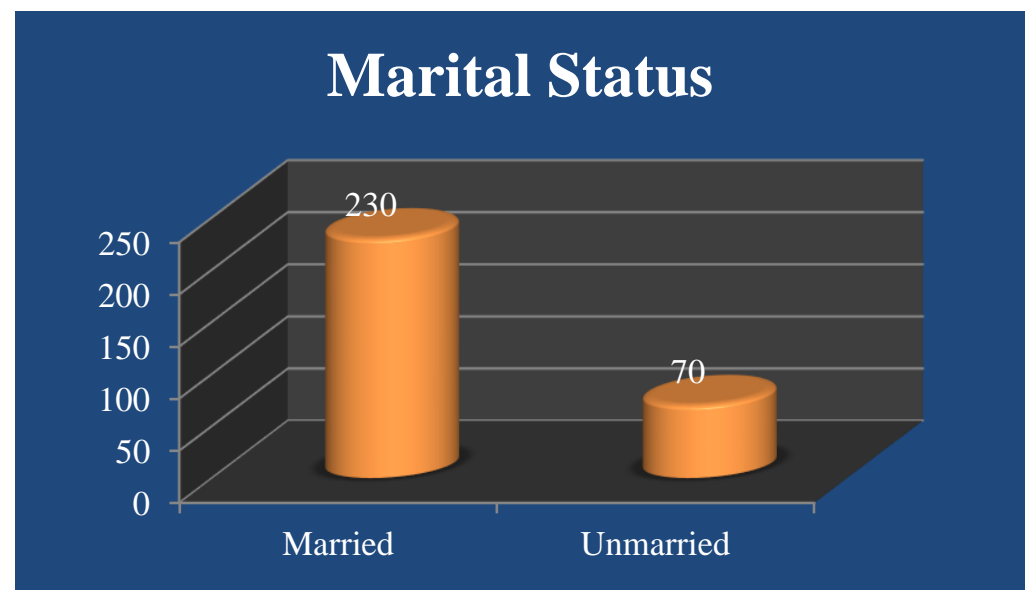

Figure 3

\section{Educational qualification of the respondents}

Table 4:Educational qualification of the respondents

\begin{tabular}{|l|l|l|}
\hline Educational qualification & Frequency & Percentage \\
\hline School Education & 10 & 3.3 \\
\hline College Education & 100 & 33.3 \\
\hline Professional & 160 & 53.4 \\
\hline Others & 30 & 10 \\
\hline Total & 300 & 100 \\
\hline
\end{tabular}

From the above table, it can be inferred that a $53.4 \%$ of the respondents are professional and education and $10 \%$ respondents belong to others $33.3 \%$ of the respondents have completed college educational background. education and $3.3 \%$ respondents done school

\section{Educational Qualification}

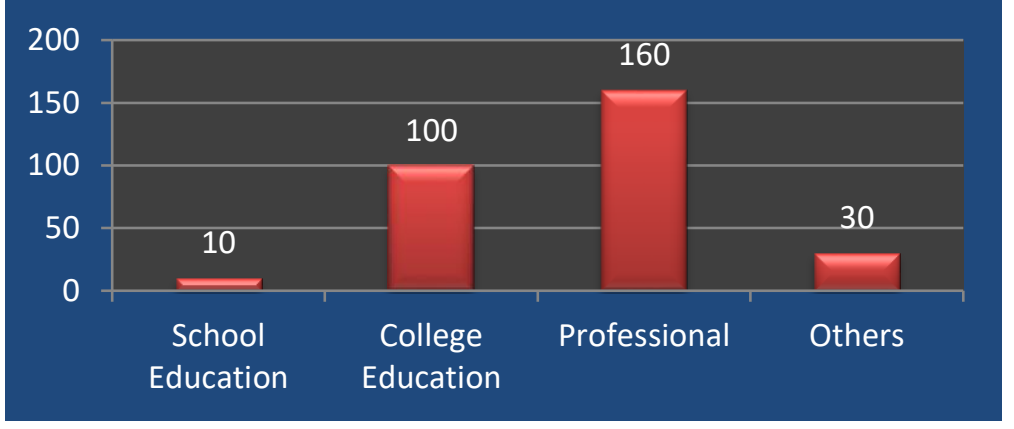

Figure 4

\section{Occupation/Profession}

Table 5: Occupation/Profession of the respondents

\begin{tabular}{|l|l|l|}
\hline Occupation/Profession & Frequency & Percentage \\
\hline Salaried & 210 & 70 \\
\hline Business & 50 & 16.7 \\
\hline Others & 40 & 13.3 \\
\hline Total & 300 & 100 \\
\hline
\end{tabular}

From the above table, it can be inferred that the majority of the respondents are salaried and $16.7 \%$ of the respondents are doing businesswhereas $13.3 \%$ of respondents have other professions. 


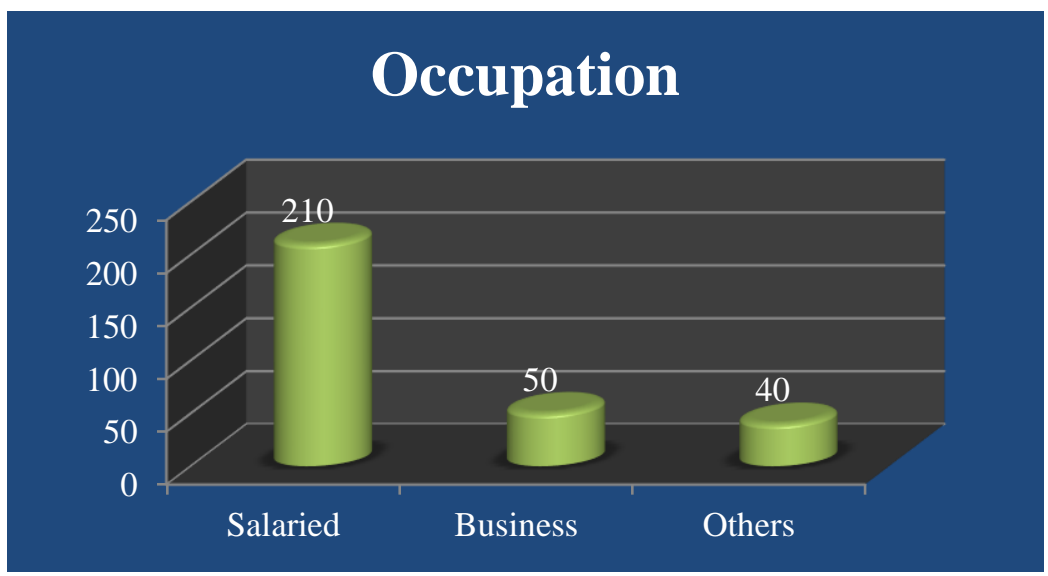

\section{Family Size}

\section{Figure 5}

Table 6: Family size of the respondents

\begin{tabular}{|l|l|l|}
\hline Family Size & Frequency & Percentage \\
\hline Less than 4 & 100 & 33.3 \\
\hline $4-6$ & 190 & 63.4 \\
\hline Above 6 & 10 & 3.3 \\
\hline Total & 300 & 100 \\
\hline
\end{tabular}

From the above table, it is clear that the majority of the respondents have a family size (4-6) and a $33.3 \%$ of the respondents have a family size less than 4 and a $3.3 \%$ of respondents have a family size above 6 .

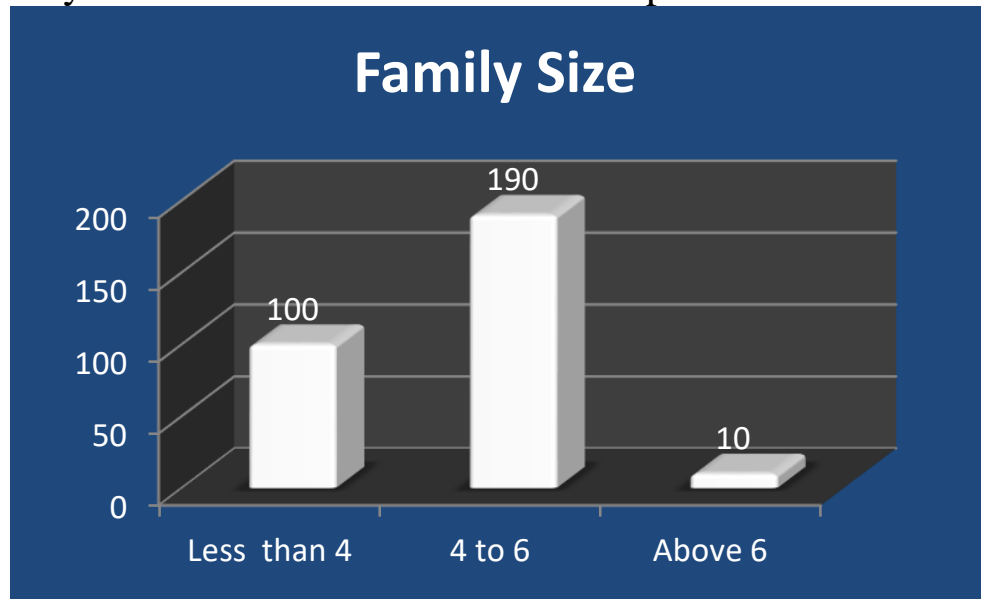

Figure 6

7. No. of earning members

Table 7:No. of earning members

\begin{tabular}{|l|l|l|}
\hline No. of earning members & Frequency & Percentage \\
\hline 1 & 100 & 33.3 \\
\hline 2 & 180 & 60 \\
\hline $3 \&$ above & 20 & 6.7 \\
\hline Total & 300 & 100 \\
\hline
\end{tabular}

From the above table, it is clear that the majority of the respondents have 2 earning members and $33.3 \%$ of respondents have 1 earning member, and $6.7 \%$ of respondents have $3 \&$ above earning members. 


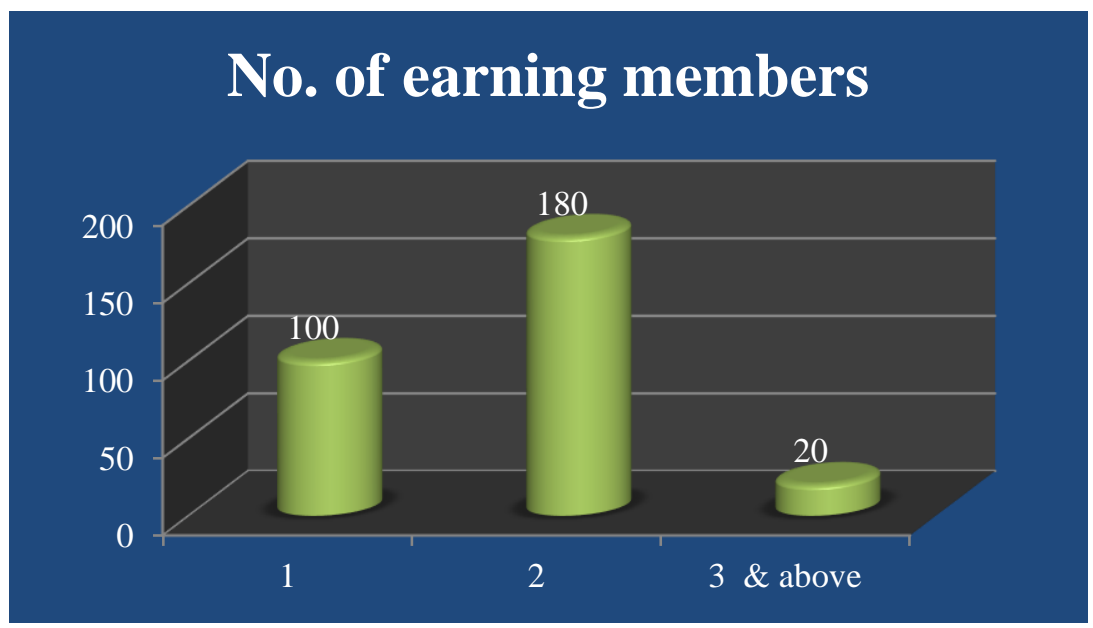

Figure 7

\section{Monthly Income}

Table 8: Monthly income of the respondents

\begin{tabular}{|l|l|l|}
\hline Monthly Income & Frequency & Percentage \\
\hline Below Rs.20,000 & 10 & 3.3 \\
\hline Rs.20,000 to Rs.40,000 & 110 & 36.7 \\
\hline Rs.40,000 to Rs.60,000 & 70 & 23.3 \\
\hline Rs.60,000 to Rs.80,000 & 20 & 6.7 \\
\hline Above Rs.80,000 & 90 & 30 \\
\hline Total & 300 & 100 \\
\hline
\end{tabular}

From the above table, it is inferred that $36.7 \%$ of respondents have a monthly income of Rs.20,000 to 40,000. $30 \%$ of the respondents have monthly income above Rs.80,000. $23.3 \%$ of the respondents have a monthly income of Rs.40,000 to Rs.60,000. 6.7\% of the respondents have monthly income Rs.60,000 to rs.80,000 and 3.3\% of the respondents have a monthly income below Rs.20,000.

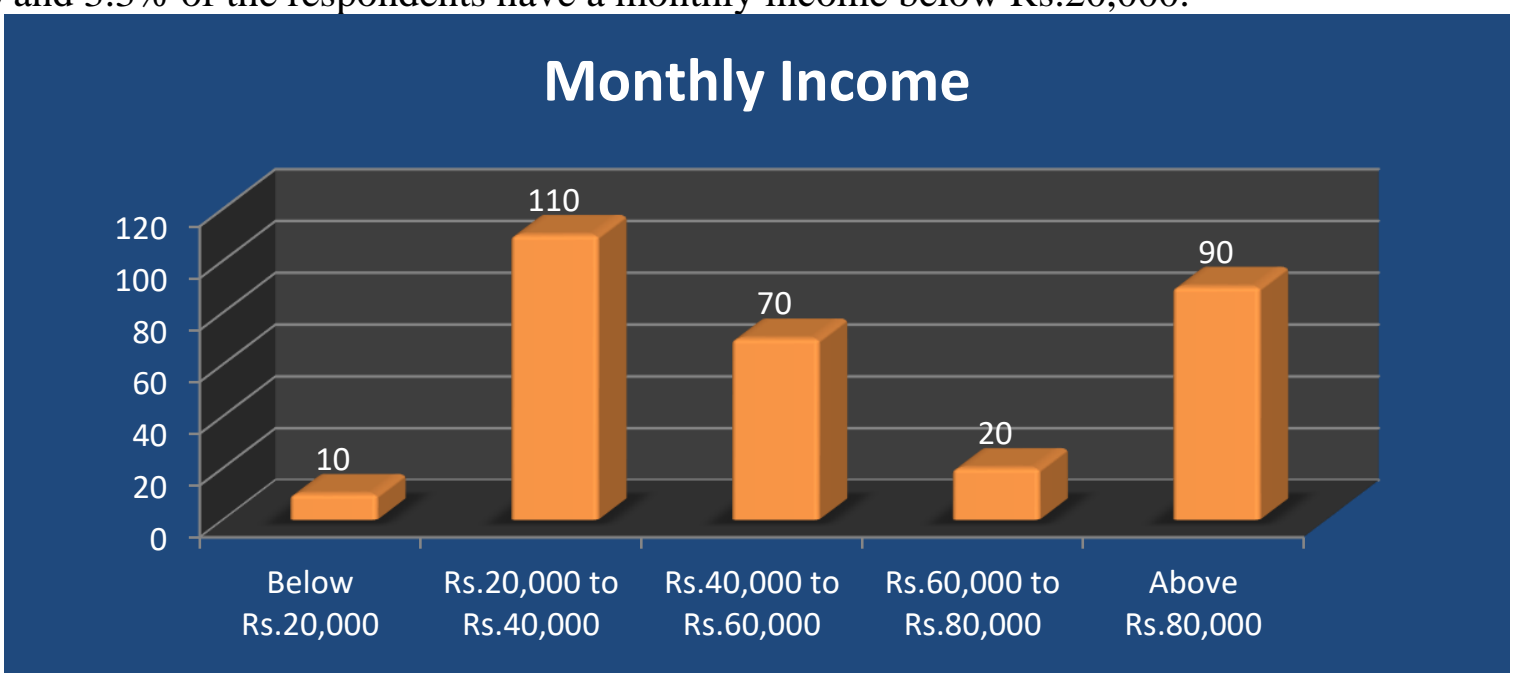

Figure 8

\section{$\underline{\text { Results of Factor Analysis }}$}

Table 9

KMO and Bartlett's Test 


\begin{tabular}{|lc|l|}
\hline $\begin{array}{l}\text { Kaiser-Meyer-Olkin } \\
\text { Adequacy. }\end{array}$ & Measure of Sampling & .465 \\
\hline $\begin{array}{l}\text { Bartlett's Test } \\
\text { Sphericity }\end{array}$ & of Approx. Chi-Square & 618.334 \\
\hline & df & 36 \\
\hline & Sig. & .000 \\
\hline
\end{tabular}

- KMO and Bartlett's Test: Bartlett's test is the indication of the strength of the relationship among variables. Here significance is less than 0.05. It means that the correlation matrix is not an identity matrix.

Table 10

\begin{tabular}{|c|c|c|}
\hline \multicolumn{3}{|c|}{ Communalities } \\
\hline & Initial & Extraction \\
\hline Shares & 1.000 & .840 \\
\hline Debentures/Bonds & 1.000 & .847 \\
\hline Stock Futures \& Options & $\mathrm{s} 1.000$ & .914 \\
\hline Mutual Funds & 1.000 & .489 \\
\hline $\begin{array}{lr}\text { National } & \text { Saving } \\
\text { Cetificate/ } & \text { Publi } \\
\text { Provident Fund/Providec } \\
\text { Fund }\end{array}$ & $\begin{array}{ll}\mathrm{g} & 1.000 \\
\mathrm{c} & \\
\mathrm{d} & \end{array}$ & .850 \\
\hline Fixed Deposits & 1.000 & .764 \\
\hline Insurance Polices & 1.000 & .766 \\
\hline Real Estate & 1.000 & .691 \\
\hline Gold/Silver & 1.000 & .566 \\
\hline $\begin{array}{l}\text { Extraction Method: I } \\
\text { Analysis. }\end{array}$ & Principal & Componen \\
\hline
\end{tabular}

- Communalities

The above table shows communalities. It explains how much of the variance (i.e. the communality value which should be more than 0.5 to be considered for further analysis. Else these variables are to be removed from further steps factor analysis) in the variables has been accounted for by the extracted factors.

\section{Table 11}

\begin{tabular}{|c|c|c|c|c|c|c|c|c|c|}
\hline \multicolumn{10}{|c|}{ Total Variance Explained } \\
\hline \multirow[b]{2}{*}{ Component } & \multicolumn{3}{|c|}{ Initial Eigenvalues } & \multicolumn{3}{|c|}{$\begin{array}{c}\text { Extraction Sums of Squared } \\
\text { Loadings }\end{array}$} & \multicolumn{3}{|c|}{$\begin{array}{c}\text { Rotation Sums of Squared } \\
\text { Loadings }\end{array}$} \\
\hline & tTotal & $\begin{array}{c}\% \text { of } \\
\text { Variance }\end{array}$ & $\begin{array}{c}\text { Cumulative } \\
\%\end{array}$ & Total & $\begin{array}{c}\% \text { of } \\
\text { Variance }\end{array}$ & $\begin{array}{c}\text { Cumulative } \\
\%\end{array}$ & Total & $\begin{array}{c}\% \text { of } \\
\text { Variance }\end{array}$ & $\begin{array}{c}\text { Cumulative } \\
\%\end{array}$ \\
\hline 1 & 2.913 & 32.370 & 32.370 & 2.913 & 32.370 & 32.370 & 2.740 & 30.447 & 30.447 \\
\hline 2 & 2.713 & 30.149 & 62.519 & 2.713 & 30.149 & 62.519 & 2.709 & 30.101 & 60.549 \\
\hline 3 & 1.101 & 12.236 & 74.755 & 1.101 & 12.236 & 74.755 & 1.279 & 14.206 & 74.755 \\
\hline 4 & .863 & 9.593 & 84.348 & & & & & & \\
\hline 5 & .542 & 6.024 & 90.372 & & & & & & \\
\hline 6 & .487 & 5.409 & 95.781 & & & & & & \\
\hline 7 & .186 & 2.071 & 97.852 & & & & & & \\
\hline 8 & .139 & 1.543 & 99.395 & & & & & & \\
\hline
\end{tabular}


9

\begin{tabular}{|l|l|l|}
.054 & .605 & 100.000 \\
\hline
\end{tabular}

Extraction Method: Principal Component Analysis.

- Total variance explained: Eigenvalue reflects the number of extracted factors whose sum should be equal to some items that are subjected to factor analysis. The above table shows all the factors extractable from the analysis along with their eigenvalues.

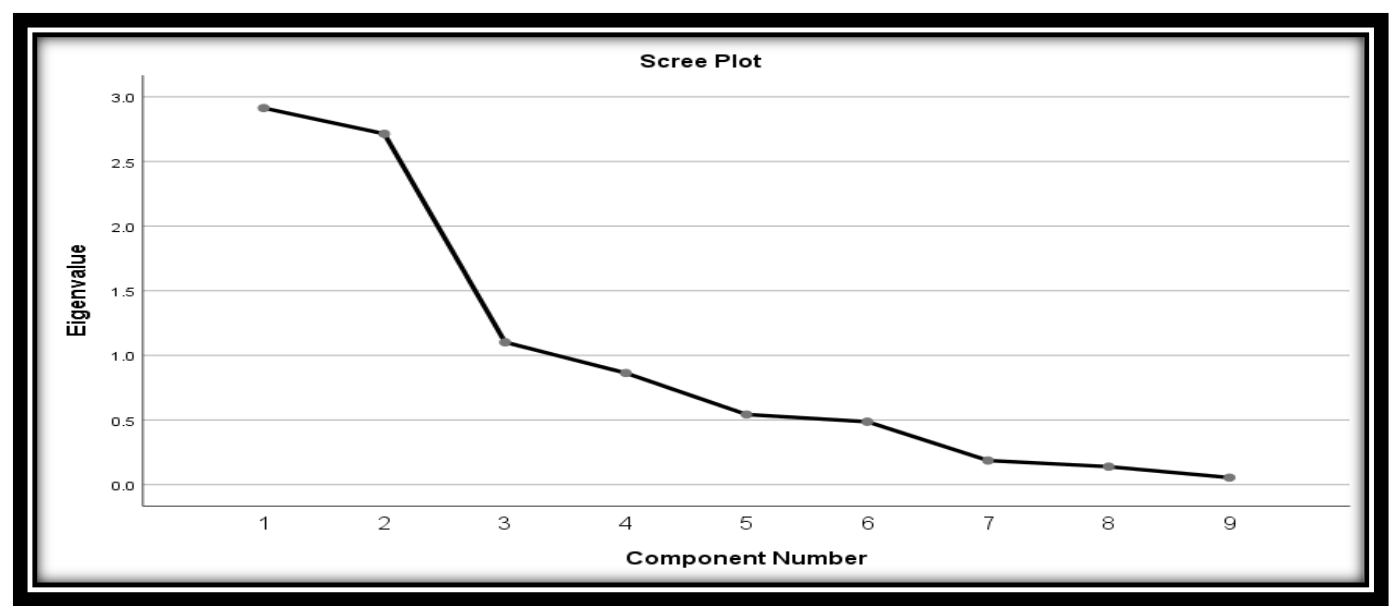

Figure 9

- Scree plot

The scree plot is a graph of the eigenvalues against all the factors. The graph is useful for determining how many factors to retain. The point of interest is where the curve starts to flatten. It can be seen that the curve begins to flatten between factors 3 and 4 . Note also that factor 4 onwards have an eigenvalue of less than 1 , so only three factors have been retained.

Table 12

\begin{tabular}{|c|c|c|c|}
\hline \multicolumn{4}{|c|}{ Component Matrix $^{\mathrm{a}}$} \\
\hline & \multicolumn{3}{|c|}{ Component } \\
\hline & 1 & 2 & 3 \\
\hline Shares & .793 & .397 & -.233 \\
\hline Debentures/Bonds & .039 & .911 & -.127 \\
\hline Stock Futures \& Options & .387 & .538 & .690 \\
\hline Mutual Funds & .273 & .640 & -.067 \\
\hline 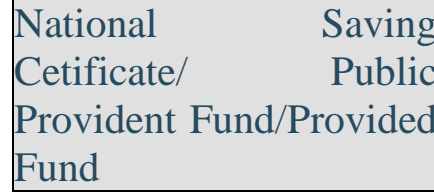 & .405 & -.486 & .670 \\
\hline Fixed Deposits & -.641 & .528 & .272 \\
\hline Insurance Polices & -.514 & .700 & .107 \\
\hline Real Estate & .816 & .095 & -.127 \\
\hline Gold/Silver & .744 & .115 & .003 \\
\hline
\end{tabular}

- Component matrix 
The above table shows the loadings (extracted values of each item under 3 variables) of the Nine variables on the three factors extracted. The higher the absolute value of the loading, the more the factor contributes to the variable (We have extracted three variables wherein the 9 items are divided into 3 variables according to most important items which similar responses in component 1 and simultaneously in component 2 and 3 ).

\section{$\underline{\text { Conclusion }}$}

Various investment options like Banks, LIC, PPF, Bonds, Mutual Funds, Real estate, Commodity Market, Gold, Equity Shares, Futures \& Options, and instruments of the Post Office like NSC \& MIS are taken for finding the best investment option. The three major components are extracted through factor analysis. It is concluded that Shares, Debentures/Bonds, and Stock Future\&Options are three investment options preferred by investors according to the responses of 300 respondents.

\section{References}

1. DeCoster, J. (1998). Overview of Factor Analysis.

2. Dr. S.Poongavanam, M. S. (2013). INVESTMENT IN INDIAN SCENARIO. Global Journal of Commerce \& Management Prespective , G.J. C.M.P., Vol. 2(2) 2013:14-17.

3. Lanjekar, P. S. (2018). A Study Of Saving And Investment Pattern of Salaried ClassPeople with Special Reference To Pune City (India). Conference: IJMER, At Mumbai, Maharashtra India.

4. Mubeen, D. T. (2018). PERCEPTION OF INDIAN WOMEN INVESTOR TOWARDS INVESTMENT IN MUTUAL FUNDS. International Journal of Applied and Advanced Scientific Research (IJAASR), Volume 3, Issue 1,2456 - 3080.

5. Pandey, I. P. (2019 ). Savings and capital formation in India. NIPFP Working paper series, https://www.nipfp.org.in/publications/wor king-papers/1866/.
6. Reddy, K. N. ( 2017). An Analysis on Investment in Mutual Fund through Systematic Investment Planning a Smart Investors Preference. International Journal of Advance Research in Computer Science and Management Studies, . 73-83. 